\title{
Fungi in deep-sea sediments of the Central Indian Basin
}

\author{
Samir Damare, Chandralata Raghukumar*, S.Raghukumar \\ National Institute of Oceanography, Dona Paula, Goa 403 004, India.
}

\begin{abstract}
Although a great amount of information is available on bacteria inhabiting deep-sea sediments, the occurrence of fungi in this environment has been poorly studied and documented. We report here the occurrence of fungi in deep-sea sediments from $\sim 5000 \mathrm{~m}$ depth in the Central Indian Basin $\left(9-16^{\circ} \mathrm{S}\right.$ and $73-76^{\circ} \mathrm{E}$ ). A total of 181 cultures of fungi, most of which belong to terrestrial sporulating species, were isolated by a variety of isolation techniques. Species of Aspergillus and non-sporulating fungi were the most common. Several yeasts were also isolated. Maximum species diversity was observed in $0-2 \mathrm{~cm}$ sections of the sediment cores. Direct staining of the sediments with Calcofluor, a fluorescent optical brightener, revealed the presence of fungal hyphae in the sediments. Immunofluorescence using polyclonal antibodies raised against a deep-sea isolate of Aspergillus terreus (\# A 4634) confirmed its presence in the form of hyphae in the sub-section from which it was isolated. A total of 25 representative species of fungi produced substantial biomass at 200 bar pressure at $30^{\circ}$ as well as at $5^{\circ} \mathrm{C}$. Many fungi showed abnormal morphology at $200 \mathrm{bar} / 5^{\circ} \mathrm{C}$. A comparison of terrestrial isolates with several deep-sea isolates indicated that the former could grow at 200 bar pressure when growth was initiated with mycelial inocula. However, spores of a deep-sea isolate Aspergillus terreus (\# A 4634), but not the terrestrial ones, showed germination at 200 bar pressure and $30^{\circ} \mathrm{C}$. Our results suggest that terrestrial species of fungi transported to the deep sea are initially stressed but may gradually adapt themselves for growth under these conditions.
\end{abstract}

Key words: Deep-sea fungi, hydrostatic pressure, diversity, Central Indian Basin

*Corresponding author, Email: lata@nio.org

Telephone: 91832 2450480; Fax: 918322450602 


\section{Introduction}

Fungi play a crucial role as saprotrophs in the ecology of terrestrial sediments. They occupy a wide variety of niches on land by virtue of their highly versatile physiological adaptations. One of the least studied habitats of fungi is the deep sea, an environment characterized by low temperature, high hydrostatic pressure and a 'feast and famine' nutrient condition (Morita, 1982; Herbert and Codd, 1986). The presence and ecological importance of deep-sea bacteria has been well recognized ever since Zobell and Morita (1957) isolated bacteria specifically adapted to grow under high pressures and termed them 'barophiles'. Yayanos (1979) obtained barophilic bacteria for the first time in pure culture. Much progress has been made with deep-sea bacteria since then with respect to their diversity (cultured and uncultured), molecular phylogeny, growth and enzyme profiles and pressure-adaptations. In contrast, one of the major groups of eukaryotic microorganisms, the fungi, has largely remained neglected. Roth et al. (1964) isolated marine fungi for the first time from oceanic waters of northwestern subtropical Atlantic Ocean down to a depth of $4450 \mathrm{~m}$. Kohlmeyer and Kohlmeyer (1979) reported obligate marine fungi from wooden panels immersed at depths of 500-3000 m. However, these fungi were not cultured. One of the first reports of fungi in deep-sea sediments was provided by Raghukumar et al. (1992), who isolated fungi from calcareous sediments of the Bay of Bengal at a depth of $965 \mathrm{~m}$ and demonstrated germination of spores of Aspergillus ustus under simulated deep-sea conditions. Subsequently, cultivation of marine yeasts (Lorenz and Molitoris, 1992) and filamentous fungi and germination of fungal spores (Zaunstöck and Molitoris, 1995) under simulated deep-sea conditions of low temperature and elevated hydrostatic pressure were reported. Takami et al. (1997) showed the presence of fungi and yeasts in sediment samples obtained from the Mariana Trench at a depth of $10,500 \mathrm{~m}$ in the Pacific Ocean. These were later identified to be Penicillium lagena and Rhodotorula mucilaginosa, respectively (Takami, 1999). The presence of fungi based on direct detection and isolation techniques in a $4.7 \mathrm{~m}$ long sediment core from the Chagos Trench in the Indian Ocean at a depth of $\sim 5000 \mathrm{~m}$ was reported recently (Raghukumar et al., 2004). However, these have been sporadic reports and not comprehensive enough to prove the existence of fungi in deep-sea sediments. We have used 
the following approach to address the occurrence and diversity of fungi from deep-sea sediments at an average depth of $5000 \mathrm{~m}$ in the Central Indian Basin (CIB): (1) Isolation of fungi by different culturing techniques and their identification; (2) direct detection of fungal hyphae in deep-sea sediments in order to confirm their growth and (3) experiments to study their growth under simulated deep-sea conditions.

\section{Methods}

\subsection{Sampling site and collection of deep-sea sediments}

Sediment samples were obtained from depths of 4900 to $5390 \mathrm{~m}$ in the Central Indian Basin $\left(9-16^{\circ} \mathrm{S}\right.$ and $\left.73-76^{\circ} \mathrm{E}\right)$ (Fig. 1) on board the Russian research vessel AA Sidorenko during 3 cruises. Samples were collected with an USNEL-type box corer of $50 \mathrm{~cm}^{3}$ size. Sampling with a box corer was possible because of the more or less flat topography of the ocean floor in the sampling area. Eleven box core samples were collected during cruise \# AAS 34 in April 2001 ( $10^{\circ} 00^{\prime} 264^{\prime \prime}$ to $10^{\circ} 10^{\prime} 364^{\prime \prime}$ S; $75^{\circ} 21^{\prime} 000^{\prime \prime}$ to $76^{\circ} 05^{\prime} 160^{\prime \prime}$ E), 7 during Cruise \# AAS 46 in June $2002\left(10^{\circ} 00^{\prime} 237^{\prime \prime}\right.$ to $10^{\circ} 02^{\prime} 661^{\prime \prime}$ S; 7559'498" to $76^{\circ} 09^{\prime} 822^{\prime \prime}$ E) and 38 during cruise \# AAS 61 in March 2003 (9 $9^{\circ} 59^{\prime} 861^{\prime \prime}$ to $16^{\circ} 00^{\prime} 047^{\prime \prime} \mathrm{S}$; $73^{\circ} 29^{\prime} 819^{\prime \prime}$ to $76^{\circ} 30^{\prime} 559^{\prime \prime}$ E). Sediment at the sampling sites was mainly radiolarian ooze, light to dark brown in color and intensely mottled indicating high bioturbation (Sharma et al., 2001). It was predominantly clayey-silt type with high water content and low shear strength and was loosely packed (Khadge, 2000). Subcores of sediments were collected from the center of the box corer with alcohol-sterilized PVC cylinders of $5 \mathrm{~cm}$ diameter. Subsections of $2 \mathrm{~cm}$ down to $10 \mathrm{~cm}$ depth and thereafter every $5 \mathrm{~cm}$ length were extruded from these sediment cores of $\sim 30-40 \mathrm{~cm}$ length directly into sterile plastic bags to avoid any aerial contaminants. The bags were closed with rubber bands and carried to the laminar flow hood in the microbiology laboratory on board.

\subsection{Isolation of fungi}

A portion of the sediment from the middle of each sub-section that had not been in contact with the walls of the PVC cylinder was removed with a flame sterilized spatula and placed in sterile vials for isolation of fungi (Raghukumar et 
al., 2004). The media used for isolations were malt extract agar (MEA), malt extract broth (MEB), corn meal agar (CMA), Sabaurauds dextrose agar (SDA), Czapek Dox agar (CDA) and Czapek Dox broth (HiMedia Pvt. Ltd., India). All the media were used at $1 / 5$ strength to simulate the low nutrient condition in the deep sea. They were prepared in seawater and fortified with streptomycin $(0.1 \mathrm{~g}$ in $100 \mathrm{ml}$ medium) and penicillin (40,000 Units in $100 \mathrm{ml}$ medium) to inhibit bacterial growth. Fungi were isolated by the following methods: 1) Dilution plating method, where $\sim 0.1 \mathrm{~g}$ of sediment was suspended in sterile seawater, vortexed for $1 \mathrm{~min}$ and $100 \mu \mathrm{l}$ aliquots spread-plated. 2) Particle plating technique (Bills and Polishook, 1994), where approximately $1 \mathrm{~g}$ of sediment slurry was sieved successively through a mesh size of $200 \mu \mathrm{m}$ and $100 \mu \mathrm{m}$ screens. The particles that passed through $200 \mu \mathrm{m}$ mesh but were retained on the $100 \mu \mathrm{m}$ mesh were spread-plated. For both the above techniques, the plates were incubated at $5^{\circ} \mathrm{C}$ at 1 bar pressure for 15-20 days. 3) Pressure incubation, in which approximately $0.5 \mathrm{~g}$ of sediments were placed in sterile plastic bags containing $2 \mathrm{ml}$ of sterile malt extract broth (MEB) and the open ends of the bags sealed with an electrical sealing machine (Quickseal, Sevana, India). The bags were placed in a deep-sea culture vessel (Tsurumi \& Seiki Co., Japan) filled with sterile water and pressurized to 300 bar pressure. The pressure vessels were immediately placed at $5^{\circ} \mathrm{C}$ and incubated for 30 days. At the end of this incubation period, $100 \mu \mathrm{l}$ of the sediment was spread-plated on nutrient media and the plates were incubated at 1 bar pressure and $30^{\circ} \mathrm{C}$ until fungal colonies appeared (within 8-10 days). Three replicate plates were maintained for each sediment sample, medium and isolation technique. Media plates were exposed to air for 10 minutes on the deck of the research vessel where the cores were received, the microbiology laboratory on board and the laminar flow inoculation hood to check for the presence of aerial contaminants. This was repeated during every sampling station.

Fungi isolated from the deep-sea sediments were subcultured and maintained on MEA slants at $5^{\circ} \mathrm{C}$. Slides of fungi were prepared in lactophenol cotton blue and microscopically examined prior to photomicrography and identification using the taxonomic keys (Domsch et al., 1980). Species of fungi isolated using all different media and techniques were pooled for each individual 
subsection of the cores and diversity measurements for each of these samples was calculated using the software PRIMER v5 (Clarke and Gorley, 2001). The results are expressed as species richness, Pielou's evenness index and Shanon Wiener diversity index $(\log 2)$. These in turn express the richness of biodiversity in each sample, the extent of even distribution of different species and proportion among total counts, respectively, in different depths of sediment cores.

For comparison, fungi were also isolated from sediments collected from shallow coral reef slopes at a depth of $30 \mathrm{~m}$ off Lakshadweep Island Kavaratti $\left(10^{\circ} 35^{\prime} \mathrm{N}\right.$ and $\left.72^{\circ} 39^{\prime} \mathrm{E}\right)$ in the Arabian Sea by the particle plating technique. Two isolates of Aspergillus terreus (MTCC 279 \& MTCC 479) and one Aspergillus sydowii (MTCC 635) culture isolated from terrestrial environments obtained from Microbial Type Culture Collection (MTCC, Chandigarh, India) were included in this study for comparison.

\subsection{Direct detection of fungi in deep-sea sediments}

About $0.5 \mathrm{~g}$ of each sediment sample in sterile vials were fixed with $5 \%$ formalin solution and stored at $5^{\circ} \mathrm{C}$ for direct detection of fungi according to the method described by Mueller and Sengbusch (1983). Aliquots of these fixed sediments were stained with $0.5 \%$ solution of sterile-filtered Calcofluor, an optical brightener (Sigma Chemicals, USA). The excess stain was washed off by centrifugation with sterile seawater. Microscopic mounts of the sediment were then examined under ultraviolet light filter (excitation wave length 330 to $385 \mathrm{~nm}$ and barrier filter BA 420) of an epifluorescence microscope (Olympus BX 60, Tokyo, Japan) to detect fluorescing fungal hyphae. Fungal hyphae and spores were photographed with a digital camera (Olympus 4.1 Mp, Tokyo, Japan). Several sediment samples were scanned for the presence of fungi after each cruise. In addition, sediments with $0.5 \mathrm{ml}$ sterile seawater were vortexed after addition of a drop of sterile detergent solution. The foam formed on the surface of trapped sediment material was pipetted out onto a sterile glass slide, stained and examined microscopically as described above. 
2.4. Detection of Aspergillus terreus Thom (isolate \# A4634) in deep-sea sediments by immunofluorescence:

The immunofluorescence technique, which has been widely used to detect specific fungi in terrestrial substrates (Jellison and Goodell, 1988; Friese and Allen, 1991; Banks et al., 1993), was employed for the purpose. Antibodies were raised commercially for Aspergillus terreus (\# A 4634), one of the most frequently isolated fungi from the deep-sea sediments of the Central Indian Basin. This isolate was obtained from core \# BC 12 at the subsurface depth of 15 to $20 \mathrm{~cm}$ during the cruise AAS $46\left(10^{\circ} 01^{\prime} \mathrm{S} ; 7^{\circ} 00^{\prime} \mathrm{E}\right.$ at a depth of $\left.5400 \mathrm{~m}\right)$. Antibodies were raised in New Zealand male white rabbits by Genei India Pvt Ltd, Bangalore, by standard protocols (Johnson and Thorpe, 1987). Thus, about $2 \mathrm{mg}$ of fungal pellet was crushed in $2 \mathrm{ml}$ of $0.15 \mathrm{M} \mathrm{NaCl}$ and centrifuged, and $1 \mathrm{ml}$ supernatant was emulsified with $1 \mathrm{ml}$ Freund's adjuvant. Fifty $\mu \mathrm{g}$ of this antigen was injected subcutaneously at multiple sites on the backs of the rabbits followed by booster doses on days $30,45,55$ and 65 . The antibody titre was monitored by Dot ELISA and yielded a value of 1: 10,000.

The presence of $A$. terreus in natural sediment samples was studied by the following method: The antiserum containing the antibodies (as supplied by Genei India Pvt Ltd., Bangalore) diluted to 1:10 with sterile phosphate buffered saline $\mathrm{pH} 7.0$ (PBS) was the minimum concentration required for detection of fluorescence of the fungus in these samples. About $\sim 0.1 \mathrm{~g}$ of the deep-sea sediment sample from which the fungus was isolated was stained with the antiserum at $25^{\circ} \mathrm{C}$ for $60 \mathrm{~min}$ followed by 5 washes, each with $1000 \mu \mathrm{l}$ PBS. The sediment was further incubated with $100 \mu \mathrm{l}$ of 1: 10 diluted secondary antibody (Genei India Pvt. Ltd), namely the goat anti-rabbit anti-serum tagged with fluorescein isothiocyanate (FITC) for $60 \mathrm{~min}$ at $25^{\circ} \mathrm{C}$. The excess stain was removed by washing the sediment 5 times with PBS. The sediment was spread evenly onto a slide and observed under an epifluorescence microscope (excitation wavelength 450-480 $\mathrm{nm}$ and barrier filter BA 515).

The reactivity of the antiserum to $A$. terreus was confirmed by growing the fungus both at 1 bar and 200 bar pressure $/ 5^{\circ}$ and $30^{\circ} \mathrm{C}$ and staining as described above. The antiserum containing the antibodies diluted to 1:100 with PBS was 
the minimum concentration required for detection of fluorescence of the fungus in culture. The absence of cross reactivity with other fungi was checked by staining an unidentified fungus, Aspergillus sp, a non-sporulating fungus and a terrestrial A. terreus (MTCC 279) with antiserum similarly and examining for the presence or absence of immunofluorescence.

\subsection{Growth of fungi under elevated hydrostatic pressure}

Representative fungi isolated by different techniques and with different nutrient media were examined for spore germination and mycelial growth under elevated hydrostatic pressures by the following methods: 1) The selected fungi were grown in MEA plates at 1 bar pressure and $30^{\circ} \mathrm{C}$ temperature, and the spores were collected by gently flooding the plates with sterile sea water. The spore suspension was appropriately diluted after haemocytometer counts, inoculated in malt extract broth (MEB) fortified with $1 \%$ glucose and $0.1 \%$ Tween 80 in pouches made with sterilized gas permeable polypropylene sheets and sealed without trapping any air bubbles. The pouches were suspended in a deep-sea culture vessel filled with sterile water and pressurized to 200 bar pressure and incubated at $30^{\circ}$ and $5^{\circ} \mathrm{C}$. Similarly prepared pouches were incubated at 1 bar pressure at $30^{\circ}$ and $5^{\circ} \mathrm{C}$ for comparison. After 3 days of incubation, the deep-sea culture vessels were decompressed gradually (at the rate of $50 \mathrm{bar} / 15 \mathrm{~min}$ ), and the percentage of germinating conidia was by counting in 20 microscope fields. For comparison, two isolates of Aspergillus terreus (MTCC 279 \& MTCC 479) and one Aspergillus sydowii (MTCC 635) culture isolated from terrestrial environments obtained from Microbial Type Culture Collection (MTCC, Chandigarh, India) were included in this study. 2) For raising mycelial biomass, cultures of 25 deep-sea fungi were grown in MEB for 3 days at 1 bar and $30^{\circ} \mathrm{C}$. Vegetative mycelium prior to the onset of sporulation was homogenized with sterile glass beads. A known weight of the finely broken mycelial suspension was inoculated in $20 \mathrm{ml}$ MEB and incubated at $30^{\circ}$ and $5^{\circ} \mathrm{C} / 200$ bar pressure as described above. After 20 days, the contents of the pouches were filtered over pre-weighed filter papers, dried to a constant dry weight and the difference between the initial and final biomass determined as mycelial dry weight (Raghukumar and Raghukumar, 1998). A similar experiment 
was carried out to compare growth of 8 deep-sea, 3 terrestrial and 3 shallow water fungi. The experiments were carried out with $5 \mathrm{ml}$ of MEB medium.

Fungi grown under high hydrostatic pressure at $5^{\circ}$ and $30^{\circ} \mathrm{C}$ were stained with Calcofluor and lactophenol cotton blue, and their morphology under different culture conditions was recorded by photomicrography.

\subsection{Gradual adaptation to growth under elevated hydrostatic pressure:}

A total of 109 of the 181 isolates obtained in this study failed to grow at 300 bar pressure. An experiment was carried out to examine if these could be gradually acclimatized to growth at elevated pressures. The cultures were initially grown at 50 bar $/ 30^{\circ} \mathrm{C}$ for 20 days, after which the pressure vessel was decompressed and the bags brought back to 1 bar pressure and checked for growth and viability upon culturing. Cultures that had grown at 50 bar pressure were transferred to fresh pouches under sterile conditions and incubated at 100 bar pressure. This process was continued at 200, 300 and 400 bar pressure. Viability of fungi after exposure to each pressure was tested by growing in MEA at $30^{\circ} \mathrm{C} / 1$ bar pressure.

\section{Results}

\subsection{Abundance and diversity}

The percentages of culturable fungi obtained by dilution plating and direct incubation of deep-sea sediments under elevated pressure were similar (Table 1). Particle plating yielded a smaller number of fungi. Sediments from shallow coral reef waters yielded much higher numbers of fungi (Table 1). The highest number of species was often obtained at 0-2 cm depth of deep-sea sediment cores, while the numbers were much less below $25 \mathrm{~cm}$ depth (Table 2). Aspergillus species were the dominant fungi isolated followed by non-sporulating and unidentified sporulating fungi. A one-way analysis of variance (ANOVA) comparing the number of species isolated from different subsections of each core showed that differences between the subsections were not significant ( $F$ value $0.34, P$-value $0.97, d . f=10,143)$. Shanon index, Pielou's evenness and species richness values were similar up to $20-25 \mathrm{~cm}$ depth, after which there 
was a marked reduction. Among the various media used for isolation of fungi, MEA and MEB followed by CMA were found to be better than the other media used. None of the media were selective for isolating specific fungi (data not shown). Details of the media used for some of the fungi are shown in Table 3.

Many of the aspergilli showed abnormal morphology immediately after isolation. These showed extremely long conidiophores with vesicles being covered by long hyphae, instead of phialides or metulae or conidia, as is typical of the genus Aspergillus (Fig. 2).

\subsection{Direct detection of fungi in sediments}

An actively germinating fungal spore was detected in sediment samples placed in dilute nutrient medium and incubated at 300 bar pressure and $5^{\circ} \mathrm{C}$ (Fig. 3). Fungal hyphae were directly detected by staining the deep-sea sediments with Calcofluor (Fig. 4). A total of 35 and 13 out of 165 and 90 sediment samples collected during the cruises AAS 61 and AAS 46, respectively, showed presence of fungi by this method.

\subsection{Detection of fungi in sediments by Immunofluorescence}

Sediment samples of the core \# BC 12 (subsection 15-20 cm, Table 3) stained with FITC-tagged antiserum against A. terreus \# A 4634 revealed fluorescing hyphae (Figs. 5a \& 5b). An unidentified organic particle in these sediments was densely colonized by the fungus. These showed positive fluorescent reaction to the antiserum (Fig. $5 \mathrm{c}$ ). The antiserum did not react with other fungi thus showing specificity for the fungus against which the antibodies were raised in rabbits. The fungus showed positive fluorescence after growth at 1 and $200 \mathrm{bar} / 5^{\circ}$ and $30^{\circ} \mathrm{C}$.

\subsection{Growth under simulated deep-sea conditions}

Out of a total of 181 fungi isolated from deep-sea sediments, a representative 25 , which showed a capability for growth at 300 bar upon initial isolation, were selected for growth under different pressures and temperatures. Details of their isolation are given in Table 3. All the fungi showed growth at 200 
bar pressure, both at $5^{\circ}$ and $30^{\circ} \mathrm{C}$ (Table 4). Thirteen fungi grew better at 200 bar $/ 5^{\circ} \mathrm{C}$, than at 200 bar $/ 30^{\circ} \mathrm{C}$. Five of these belong to Aspergillus species. All the fungi grew best at 1 bar and $30^{\circ} \mathrm{C}$, growth being 3-4 times greater than under elevated hydrostatic pressure (200 bar) at $5^{\circ}$ and $30^{\circ} \mathrm{C}$. .

Several fungi showed abnormal features when grown under elevated pressure either at $5^{\circ}$ or $30^{\circ} \mathrm{C}$. For example, A. terreus, \# A 4634 showed normal mycelial growth at 1 bar pressure at $30^{\circ}$ and $5^{\circ} \mathrm{C}$ (Fig. 6a), while hyphal swellings and constrictions occurred at $30^{\circ}$ and $5^{\circ} \mathrm{C} / 200$ bar pressure (Fig. 6b). An orangepigmented yeast showed equally good growth at $30^{\circ} \mathrm{C} / 1$ bar pressure and $5^{\circ}$ $\mathrm{C} / 200$ bar pressure as well (Figs. 7a, 7b). The conidia of Penicillium sp. (isolate \# 4615) showed regular germination at $30^{\circ} \mathrm{C} / 100$ bar pressure, while those of Aspergillus sp. (isolate \# 3454) showed swollen conidia (Figs. 8, 9). The conidia of these species showed normal germination at $30^{\circ} \mathrm{C} / 1$ bar pressure.

\subsection{Comparison of the growth of deep-sea fungi with that of terrestrial isolates} under elevated hydrostatic pressure

Spores of the terrestrial isolates Aspergillus terreus and Aspergillus sydowii totally failed to germinate at $200 \mathrm{bar} / 30^{\circ} \mathrm{C}$ (Table 5). However, $66 \%$ of the spores of the deep-sea isolate A. terreus (isolate \# A 4634) germinated under these conditions. None of these showed germination at $5^{\circ} \mathrm{C} / 200$ bar (Table 5).

Contrary to spores, both terrestrial and deep-sea isolates of fungi showed growth at $5^{\circ} \mathrm{C} / 200$ bar and $30^{\circ} \mathrm{C} / 200$ bar when mycelia were used as inocula (Table 6). The deep-sea isolates A. terreus (\# A 4634), Aspergillus sp. (\# A 61 $\mathrm{P} 4)$ and the unidentified isolate \# 3415 did not show significant difference in biomass production at $30^{\circ} \mathrm{C} / 1$ bar or 200 bar pressure. The orange yeast (\# A61P63) showed almost similar growth under all combinations of temperature and pressure. Several of the filamentous fungi showed equally good growth at $5^{\circ} \mathrm{C} / 1$ bar or 200 bar pressure (Table 6 ).

2.5. Gradual adaptation of fungi to increasing hydrostatic pressure:

A large number of the 109 fungi that did not grow at 300 bar pressure grew at 50 bar pressure (Table 7). Decreasing numbers of fungi showed viability 
and growth when they were gradually subjected to higher pressure. Only 2 strains of $A$. terreus and the yeast \# A344 grew at 300 bar and only the latter grew at 400 bar pressure.

\section{Discussion}

Studies on fungi in deep-sea sediments are fraught with the danger of contamination by fungal structures (both spores and mycelia) in the sampling devices, as well as from air on deck and in the laboratory. We have attempted to reduce this risk by exercising utmost caution, as detailed under Methods. One of the culture techniques that we used for enhancing recovery of native fungi was the particle plating method, which employs culturing from particles in the 100 $200 \mu \mathrm{m}$ size range, thus considerably removing loose spores (Bills and Polishook, 1994). Further, sediment samples were placed in a diluted nutrient medium under elevated hydrostatic pressure and low temperature immediately upon recovery of sediments on board and incubated for 30 days prior to isolating fungi from them. We believe that this would minimize possible 'deep-sea nonadapted' aerial contaminants.

The most direct evidence for the occurrence of fungi in the deep-sea sediments from $\sim 5000 \mathrm{~m}$ depth was obtained by staining sediment samples with the optical brightener Calcofluor, which enhances fluorescence of cellulose and chitin, the latter being a characteristic fungal cell wall component (Mueller and Sengbusch, 1983). The mycelial state of fungi represents an actively growing vegetative condition within or interspersed among organic particles. We believe that the presence of organic particles in the deep-sea sediment samples (Fig. 5c) allows growth of fungal mycelia therein. The total organic matter (TOM) in these sediments was in the range of 4 to $12 \mathrm{mg} \mathrm{g}^{-1}$ dry sediment. Labile organic matter (LOM) comprising carbohydrate, protein and lipids varied from 0.5 to $1.5 \mathrm{mg} \mathrm{g}^{-1}$ dry sediment (Raghukumar et al., 2001). Evidence for the presence of Several megafaunal species and faecal casts of benthic animals have been observed in the Central Indian Basin using deep-sea video-photography (Rodrigues et al., 2001). Hence, presence of fungi in the deep-sea sediments may be expected in view of the abundant organic material present therein. 
The frequency of fungal species recovered from various depths in the sediment core was not significantly different (Table 2), indicating the homogenous nature of the sediment in the areas sampled. Raghukumar et al. (2001) have earlier reported the homogenous distribution of total organic matter and labile organic matter in these sediments. This might be the result of high bioturbation by sediment in-fauna (Ingole et al., 2001). The homogeneous nature of sediments at different depths was further indicated by the similar Shanon index and species richness values (Table 2).

The identity of fungi present in the sediments cannot be determined without culturing. All the different culture techniques that we employed yielded filamentous fungi, belonging to the genera such as Aspergillus, Penicillium, Cladosporium, Curvularia, Fusarium and several non-sporulating forms which are known from terrestrial habitats. Aspergillus terreus was one of the most common fungi isolated. Colonies of the terrestrial fungi in our isolations from the sediments might have resulted either from dormant spores or actively growing mycelia. Hence, presuming that the fungi that we found in the deep-sea sediments originated from land, the following sequence of events can be deduced from our experimental and observational approach to understand if such fungi were capable of an active mycelial growth under the elevated hydrostatic pressures and cold temperatures of the deep sea.

Fungi may be transported to the sea both in the form of hyphae growing on organic particles from land and in the form of spores transported to the sea by wind. There are several ways in which fungi can be transported in their mycelial forms to the deep sea. Large particulate organic matter, such as decaying leaves and wood, may be carried offshore and eventually sink. Turner (1973) has described the presence of 'islands of wood' in the deep-sea, which seem to be due to sinking of waterlogged wood washed offshore during monsoons in the tropics or spring runoff in high latitudes. She further speculated that such "persistent but constantly shifting 'islands' of wood might bring in saprophytic species that serve as dispersal centers and contribute to habitat diversity, niche specialization and enrichment". Even substrates of purely oceanic origin, such as marine aggregates in surface waters, may not be devoid of fungi. We have 
observed fungal colonization of transparent exopolysaccharides (TEPS) collected from coastal Arabian Sea waters (Figs. 10a, 10b) and also oceanic waters. Many species of fungi, when transported to the deep-sea from land in the form of hyphae, may be capable of growth under the prevalent high hydrostatic pressures and low temperature. Thus, in one experiment, all the fungi that we tested, irrespective of whether they were isolated from deep-sea sediments, shallow coral reef lagoon waters or terrestrial sources, grew and produced substantial biomass when mycelial inocula were used (Table 6). Contrary to hyphae, spores may be poor candidates for propagation of fungi in the deep-sea sediments. None of the four fungi that we tested, including 3 terrestrial and 1 deep-sea isolate, germinated at $5^{\circ} \mathrm{C}$ at 1 or 200 bar. The terrestrial isolates germinated very poorly at 200 bar $30^{\circ} \mathrm{C}$, while the marine isolate showed substantial germination (Table 5). Thus, pressure appears to have different effects on mycelium and spores of fungi. Alternatively, their germination under deep-sea conditions may be substantially delayed, as observed by Zaunstőck and Molitoris (1995).

Many of the fungi that reach the sea floor as mycelia may initially be highly stressed by the extreme conditions existing therein. Thus, several fungi showed swellings in their hyphae and other abnormalities when grown at $200 \mathrm{bar} / 5^{\circ} \mathrm{C}$ (Fig. 2). The abnormalities were much less at 200 bar $/ 30^{\circ} \mathrm{C}$, suggesting that the low temperature was more adverse than the high pressure itself. Lorenz (1993) has shown abnormal growth of $A$. ustus under elevated hydrostatic pressure. Those fungi that adapt themselves may eventually be able to grow normally under deep-sea conditions. Thus, the isolate \# A 3415, an unidentified fungus, grew in the form of normal hyphae under simulated deep-sea conditions. Use of the immunofluorescence technique revealed normal hyphae of $A$. terreus \# 4634 in the deep-sea sediment collected from a $15-20 \mathrm{~cm}$ core (Fig. 4). Aspergilli are physiologically very versatile and are some of the most successful fungi in colonizing a variety of substrates on land (Domsch et al., 1980). The fungi that we isolated corresponded morphologically to known terrestrial species. However, deep-sea adaptations might have resulted in genetic modifications. This aspect needs to be addressed in the future. 
Based on studies on Escherichia coli, Sato et al. (1995) hypothesized that since life originated in the deep-sea environment, a high pressure gene expression system is conserved in living organisms, even if they are presently adapted to atmospheric pressure. Bartlett (2002) also reported that bacterial and archaeal piezophiles in culture are closely related to shallow-water microbes which are not piezophilic. Thus it appears that "high-pressure selection has not required the evolution of dramatically different lineages of life". These studies further support our observation on growth of terrestrial fungi under elevated hydrostatic pressure.

The effect of hydrostatic pressure varies according to the species being considered. While the biomass of $A$. terreus (\#A 4634) was not significantly reduced after cultivation under elevated hydrostatic pressure (Table 6), the yeast \# A344 showed reduction in biomass under such conditions. Morphologically, the yeast cells showed pseudomycelium formation under the simulated deep-sea conditions and $A$. terreus showed abnormal hyphal swellings (Fig. 6B). Nagahama et al. (2001) have reported 99 yeast strains from the deep-sea floor in the northwest Pacific Ocean, but pressure tolerance and growth of these under elevated hydrostatic pressure is not known. Lorenz and Molitoris (1997) have shown growth of the basidiomycetous yeast Rhodosporidium sphaerocarpum at 400 bar pressure with some abnormalities.

We also found that numerous isolates obtained from the deep sea did not grow at $200 \mathrm{bar} / 5^{\circ} \mathrm{C}$, even with mycelial inocula. Hence, it is possible that not all fungi that reach the deep sea show growth under these conditions. However, a few of them may still be capable of gradual adaptation to the deep-sea conditions. Thus, out of the 109 fungi that did not grow at 300 bar pressure, a yeast could be gradually be adapted to grow at 400 bar pressure and three fungi were able to grow at 300 bar pressure (Table 7). These were once again a strain of $A$. terreus and a yeast. It has been shown that yeast cells show increased barotolerance after heat-shock treatment, and it has been proposed that the effect of hydrostatic pressure on yeast is analogous to high temperatures and that a heat-shock pretreatment is able to induce barotolerance (Iwahashi et al., 1991). 
In conclusion, we demonstrate in this study the active presence of fungi in deep-sea sediments by direct detection using Calcofluor stain, immunofluorescence detection using polyclonal antibodies, culturing and experimentation under simulated deep-sea conditions. Some of the cultures obtained, grew under elevated hydrostatic pressure, while some did so following a period of adaptation. A few others grew under elevated pressure but showed abnormalities in their morphology. The present study confirms the earlier hypothesis (Raghukumar and Raghukumar, 1998) that terrestrial fungi blown to the sea surface and sinking to the deep-sea sediments have adapted to the alien environmental conditions. Besides, it also suggests that these are some of the hardiest forms that can adapt and survive under the most extreme conditions.

\section{Acknowledgements}

C. Raghukumar is thankful to the Department of Biotechnology, New Delhi, for the grant BT/PR1193/AAQ/03/102/2000. The first author is thankful for the fellowship provided by DBT and to the Director, NIO, for the facility. The oceanic cruises to the Central Indian Ocean were financed by the Department of Ocean Development, New Delhi. We are indebted to Dr. Rahul Sharma, the project leader of the program on "Environmental Impact Assessment of polymetallic nodule mining in the Central Indian Basin" for all the support and logistics during the research cruises. We acknowledge the help and cooperation of the Captain and crew of the Russian research vessel AA Sidorenko during long voyages to the Central Indian Ocean. This is NIO's contribution No. 4032. 


\section{References}

Banks, J.N., Cox, S.J., Northway, B.J., 1993. Polyclonal and monoclonal antibodies to field and storage fungi. International Biodeterioration and Biodegradation 32, 137-144.

Bartlett, D.H., 2002. Pressure effects on in vivo microbial processes. Biochemica et Biophysica Acta 1595, 367-381.

Bills, G.F., Polishook, J.D., 1994. Abundance and diversity of microfungi in leaf litter of a lowland rain forest in Costa Rica. Mycologia 86, 187-198.

Clarke, K.R., Gorley R.N., 2001. PRIMER v5 (Plymouth Routines in Multivariate Ecological Research).

Domsch, K.H., Gams, W., Anderson, T-H., 1980. Compendium of soil fungi. Academic Press, London.

Friese, C.F., Allen M.F., 1991. Tracking fates of exotic and local VA mycorrhizal fungi: methods and patterns. Agriculture, Ecosystems and Environment 34, 87-96.

Herbert, R.A., Codd, G.A., 1986. Microbes in extreme environments. Academic Press, London.

Ingole, B.S., Ansari, Z.A., Rathod, V., Rodrigues, N., 2001. Response of deepsea macrobenthos to a small-scale environmental disturbance. Deep-Sea Research II 48, 3401-3410.

Iwahashi, H., Kaul, S.C., Obuch, K., Komatsu, Y., 1991. Induction of barotolerance by heat shock treatment in yeast. FEMS Microbiology Letters $80,325-328$.

Jellison, J., Goodell, B.S., 1988. Immunological characterization of lignocellulose degradation. Biomass 15, 109-116.

Johnson, A., Thorpe, R., 1987. Immunochemistry in practice. Blackwell Scientific Publ. Oxford.

Khadge, N.H., 2000. Geotechnical properties of surface sediments in the INDEX area. Marine Georesources and Geotechnology 18, 251-258. 
Kohlmeyer, J., Kohlmeyer, E., 1979, Marine Mycology. The higher fungi. Academic Press, New York.

Lorenz, R., 1993. Kultivierung mariner Pilze unter erhöhtem hydrostatischen Druck. Ph.D. Thesis, University of Regensburg, Germany.

Lorenz, R., Molitoris, H.P., 1992. High-pressure cultivation of marine fungi: cultivation experiments. In: Balny C., Hayashi, R., Masson, P.(Eds.), High pressure and biotechnology. John Libbey \& Co., London, pp. 315-319.

Lorenz, R., Molitoris, H.P., 1997. Cultivation of fungi under simulated deep-sea conditions. Mycological Research 101, 1355-1365.

Morita, R.Y., 1982. Starvation survival of heterotrophs in the marine environment. Advances in Microbial Ecology 6, 171-198.

Mueller, V., Sengbusch, P.V., 1983. Visualization of aquatic fungi (Chytridiales) parasitizing on algae by means of induced fluorescence. Archiv fuer Hydrobiologie 97, 471-485.

Nagahama, T., Hamamoto, M., Nakase, T., Takami, H., Horikoshi, K., 2001. Distribution and identification of red yeasts in deep-sea environments around the northwest Pacific Ocean. Antonie Van Leeuwenhoek 80, 101110.

Raghukumar, C., Raghukumar, S., Sharma, S., Chandramohan, D., 1992. Endolithic fungi from deep-sea calcareous substrata: isolation and laboratory studies. In: Desai, B.N. (Ed.), Oceanography of the Indian Ocean. Oxford IBH Publ., New Delhi.

Raghukumar, C., Raghukumar, S., 1998. Barotolerance of fungi isolated from deep-sea sediments of the Indian Ocean. Aquatic Microbial Ecology 15, 153-163.

Raghukumar, C., Loka Bharathi, P. A., Ansari, Z.A., Nair, S., Ingole, B., Sheelu, G., Mohandass, C., Nath, B.N. Rodrigues, N., 2001. Bacterial standing stock, meiofauna and sediment-nutrient characteristics: indicators of benthic disturbance in the Central Indian Ocean. Deep-Sea Research II, 3381-3399. 
Raghukumar, C., Raghukumar, S., Sheelu, G., Gupta S.M., Nath, B.N. Rao, B.R., 2004. Buried in time: culturable fungi in a deep-sea sediment core from the Chagos Trench, Indian Ocean. Deep-Sea Research I 51, 17591768.

Rodrigues, N., Sharma, S., Nath, B.N., 2001. Impact of benthic disturbance on megafauna in the Central Indian Basin. Deep-Sea Research II, 34113426.

Roth, F.J., Orpurt, P.A. Ahearn, D.J., 1964. Occurrence and distribution of fungi in a subtropical marine environment. Canadian Journal of Botany 42, 375383.

Sato, T., Kato, C., Horikoshi, K., 1995. Effect of high pressure on gene expression by lac and tac promoters in Escherichia coli. Journal of Marine Biotechnology 3, 89-92.

Sharma, R., Nath, B.N., Parthiban, G., Jai Sankar, S., 2001. Sediment redistribution during simulated benthic disturbance and its implications on deep seabed mining. Deep-Sea Research II 48, 3363-3380.

Takami, H., Inoue, A., Fuji, F., Horikoshi, K., 1997. Microbial flora in the deepest sea mud of the Mariana Trench. FEMS Microbiology Letters 152, 279-285.

Takami, H., 1999. Isolation and characterization of microorganisms from deepsea mud. In: Horikoshi, K., Tsujii K. (Eds.), Extremophiles in deep-sea environments. Springer-Verlag, Tokyo, pp. 3-26.

Turner, R.D., 1973. Wood-boring bivalves, opportunistic species in the deep-sea. Science 180, 1377-1379.

Yayanos, A.A., 1979. Isolation of a deep-sea barophilic bacterium and some of its growth characteristics. Science 205, 808-810.

Zaunstőck, B., Molitoris, H.P.1995. Germination of fungal spores under deep-sea conditions. Abstr. VI International Marine Mycology Symposium, Portsmouth.

ZoBell, C.E., Morita, R.Y., 1957. Barophilic bacteria in some deep-sea sediments. Journal of Bacteriology 73, 563-568. 
Table1. Number of fungi isolated by various techniques

\begin{tabular}{|c|c|c|c|c|}
\hline \multicolumn{2}{|c|}{ Source } & \multirow{2}{*}{$\begin{array}{c}\begin{array}{c}\text { Particle } \\
\text { plating }\end{array} \\
376\end{array}$} & \multirow{2}{*}{$\begin{array}{c}\text { Dilution } \\
\text { plating } \\
\\
\\
72\end{array}$} & \multirow{2}{*}{ 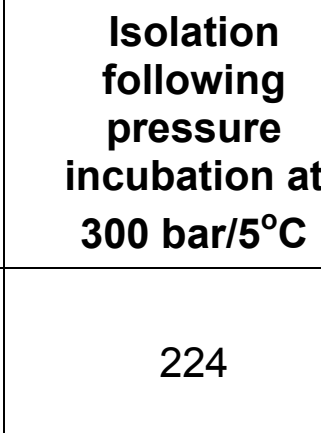 } \\
\hline Deep sea & $\begin{array}{c}\text { Total number of } \\
\text { sediment samples } \\
\text { used }\end{array}$ & & & \\
\hline & $\begin{array}{l}\text { Number of fungi } \\
\text { isolated }\end{array}$ & 65 & 28 & 88 \\
\hline & $\begin{array}{l}\% \text { frequency of } \\
\text { occurrence }\end{array}$ & 17 & 39 & 39 \\
\hline \multirow[t]{3}{*}{$\begin{array}{c}\text { Shallow } \\
\text { water }\end{array}$} & $\begin{array}{c}\text { Total number of } \\
\text { sediment samples } \\
\text { used }\end{array}$ & 16 & \multirow{3}{*}{\multicolumn{2}{|c|}{ Not done }} \\
\hline & $\begin{array}{l}\text { Number of fungi } \\
\text { isolated }\end{array}$ & 26 & & \\
\hline & $\begin{array}{l}\% \text { frequency of } \\
\text { occurrence }\end{array}$ & 163 & & \\
\hline
\end{tabular}




\begin{tabular}{|c|c|c|c|c|c|c|c|c|c|c|c|c|c|c|c|c|c|c|c|}
\hline & $\begin{array}{l}\text { O } \\
\text { ஸे } \\
\text { மூ }\end{array}$ & $\infty$ & $\stackrel{\sim}{ }$ & $\stackrel{m}{\sim}$ & 1 & ' & ' & ' & ' & 1 & $\stackrel{m}{2}$ & $\stackrel{m}{\sim}$ & $\overparen{\bullet}$ & ' & ' & 1 & 今. & & $\underset{r}{\stackrel{8}{*}}$ \\
\hline & 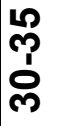 & $m$ & $\stackrel{\sim}{\sim}$ & ڤั & $\infty$ & I & ' & 1 & $\stackrel{\sim}{\sim}$ & ' & 1 & $\stackrel{n}{\sim}$ & $\infty$ & ' & I & ' & ?ִ & & مִ \\
\hline & 品 & $\check{F}$ & 유 & $\stackrel{\infty}{\sigma}$ & ( & I & 1 & I & ' & 1 & 1 & மே & $\ddot{m}$ & I & I & I & 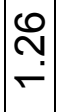 & & $\stackrel{\sim}{\stackrel{n}{r}}$ \\
\hline & 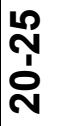 & N & مَم & $\stackrel{\Xi}{\Xi}$ & $\stackrel{ \pm}{ \pm}$ & $\sigma$ & ' & $\sigma$ & م & & 1 & $\stackrel{\infty}{\infty}$ & $\stackrel{\infty}{N}$ & م) & ' & م & $\begin{array}{l}0 \\
0 \\
\\
\end{array}$ & & م \\
\hline $\begin{array}{l}\widetilde{E} \\
\mathcal{U} \\
0\end{array}$ & 尽 & $\stackrel{0}{\circ}$ & $\mathscr{L}$ & 0 & $\stackrel{\sigma}{\circ}$ & $m$ & ' & $m$ & $\stackrel{m}{\sim}$ & 1 & 1 & 0 & $\bar{m}$ & I & I & ' & $\infty^{\infty}$ & & $\frac{\sigma}{\sim}$ \\
\hline : & $\frac{n}{o}$ & 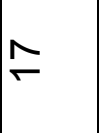 & $\mathscr{0}$ & $\stackrel{N}{\sim}$ & $\stackrel{\infty}{\sim}$ & $\stackrel{N}{\sim}$ & 0 & 0 & 0 & ' & 1 & $\stackrel{\infty}{\sim}$ & $\stackrel{\sim}{\sim}$ & I & I & I & 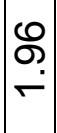 & & 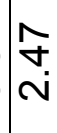 \\
\hline & $\frac{0}{\infty}$ & \pm & مُ & $\stackrel{\mathbb{N}}{ }$ & $\lambda$ & $\bar{\sim}$ & $\Lambda$ & $\curvearrowright$ & $\curvearrowright$ & ' & 1 & 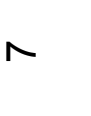 & $\underset{ }{ \pm}$ & I & I & I & бே. & & 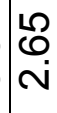 \\
\hline & 文 & $\stackrel{0}{0}$ & $\mathscr{0}$ & $\stackrel{\sim}{N}$ & $\stackrel{m}{\sim}$ & $\stackrel{9}{2}$ & 0 & ' & I & I & 1 & $m$ & (2) & ' & ' & 0 & 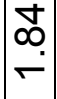 & 足 & $\frac{0}{2}$ \\
\hline & ơ & $\stackrel{\sim}{\sim}$ & مٌ & ما & $\stackrel{10}{2}$ & $\stackrel{0}{2}$ & م & $\stackrel{0}{2}$ & $\stackrel{20}{\sim}$ & ' & 1 & $\stackrel{ }{\circ}$ & $\stackrel{\sim}{N}$ & ' & ' & 10 & 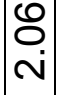 & & $\begin{array}{l}\hat{\theta} \\
\stackrel{N}{*}\end{array}$ \\
\hline & $\stackrel{J}{\sim}$ & の & صڤ & $\mp$ & م & $\stackrel{\mathscr{N}}{\sim}$ & م & 10 & ' & I & 1 & $\check{F}$ & $\underset{m}{ }$ & I & I & 10 & $\underset{\infty}{\infty}$ & & $\stackrel{\substack{\infty \\
\sim}}{N}$ \\
\hline & ஸ̀ & $\stackrel{\sim}{\sim}$ & صִ & $\infty$ & $\stackrel{\infty}{N}$ & $\stackrel{N}{\sim}$ & 1 & $\infty$ & $\nabla$ & $\nabla$ & 1 & $\stackrel{\theta}{\leftarrow}$ & $\stackrel{\bullet}{2}$ & ' & $\checkmark$ & I & ब্. & & 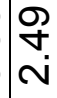 \\
\hline $\begin{array}{l}\frac{0}{0} \\
\frac{0}{\Phi} \\
\mathbb{0}\end{array}$ & & 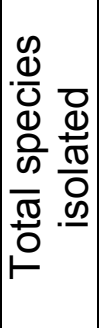 & 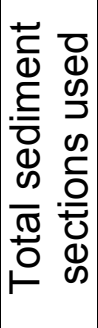 & 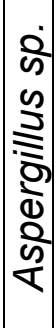 & 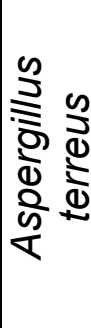 & 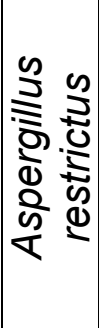 & 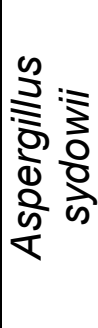 & 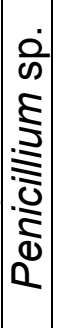 & 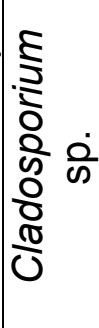 & $\begin{array}{c}\frac{0}{0} \\
\cdot \frac{0}{2} \\
\frac{0}{3} \\
\frac{1}{3} \\
0\end{array}$ & 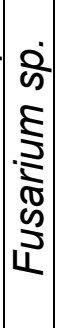 & 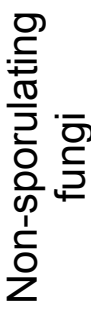 & 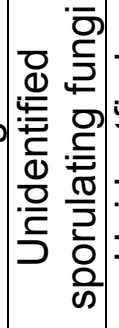 & 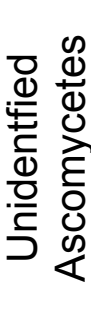 & 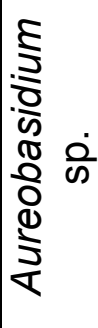 & 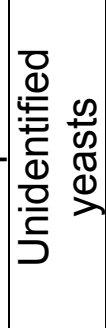 & 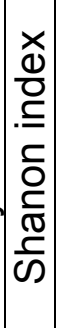 & 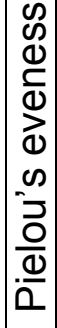 & 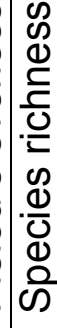 \\
\hline
\end{tabular}




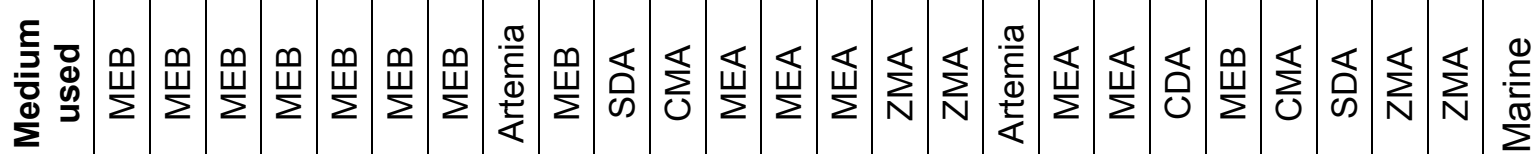

屯ั

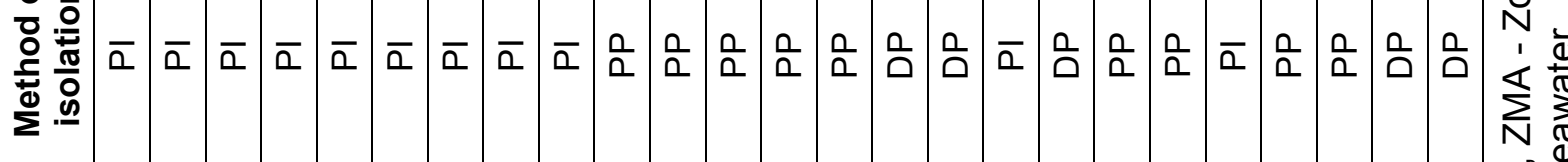

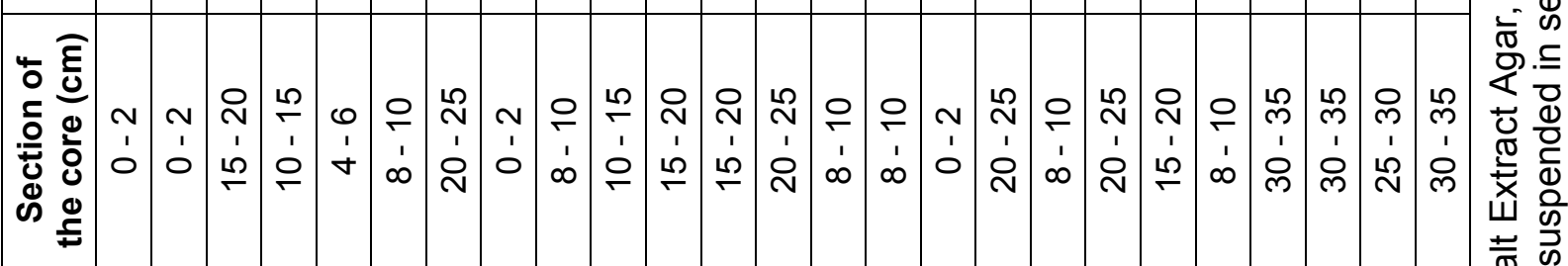

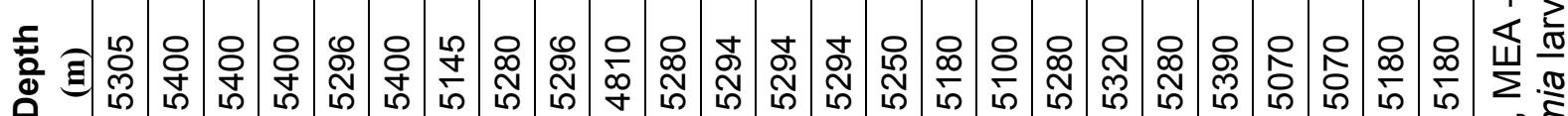

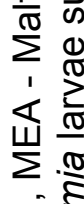

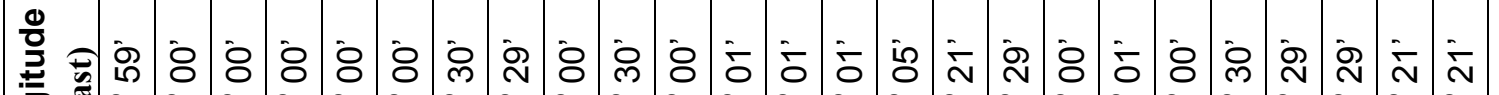

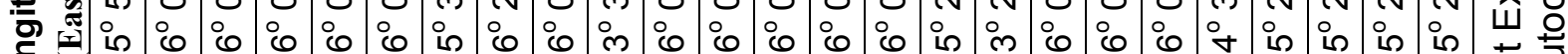
定

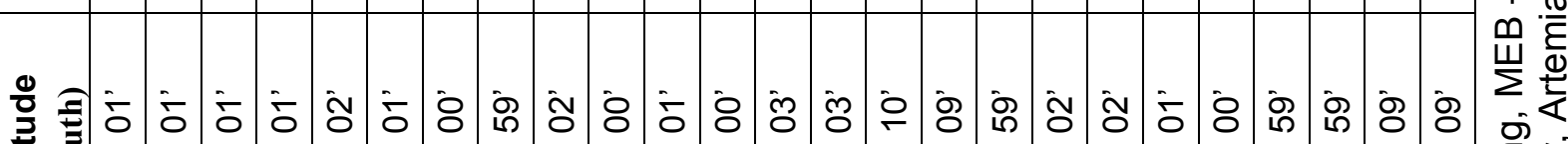
贲 完 .

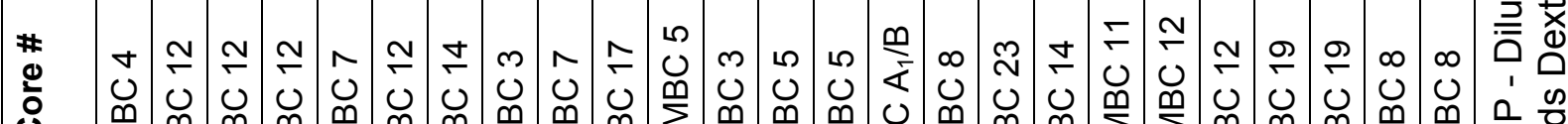
J

*

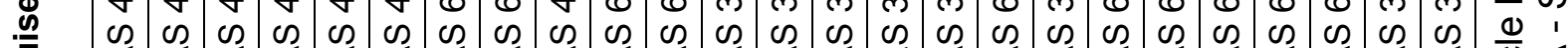
荥

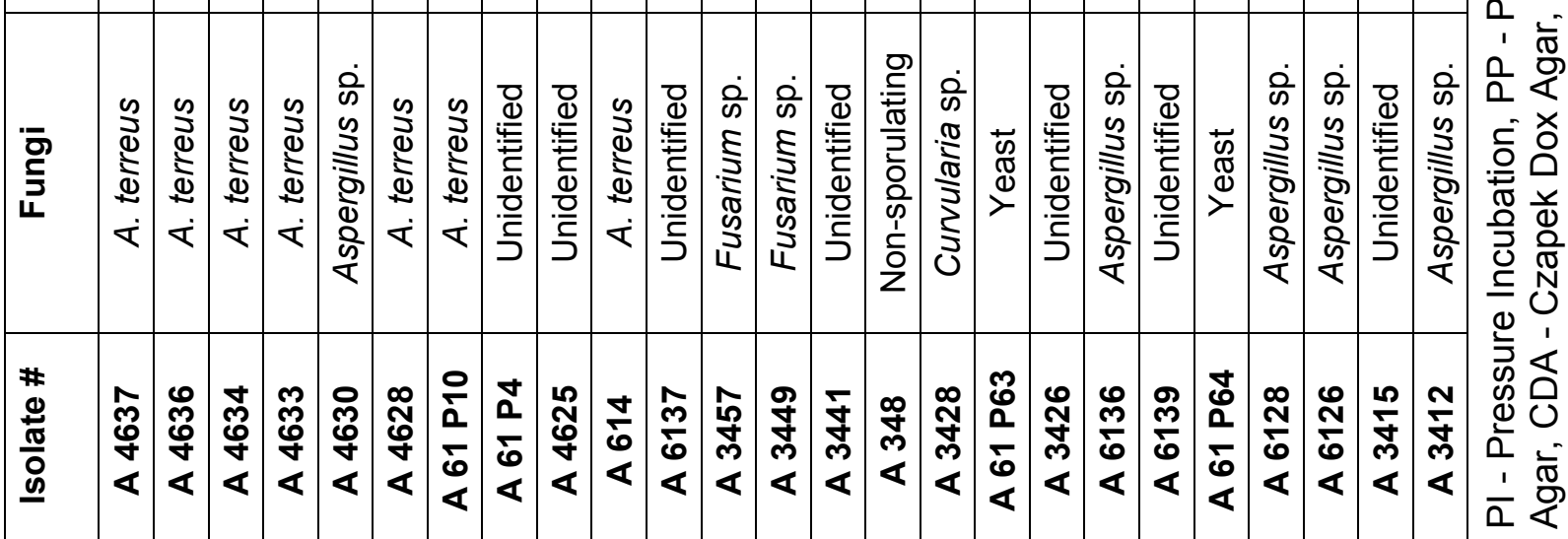


Table 4. Biomass produced by various deep-sea fungi under different pressure and temperature conditions.

\begin{tabular}{|c|c|c|c|c|}
\hline \multirow{2}{*}{ Isolate \# } & Fungi & \multicolumn{3}{|c|}{ Biomass produced (mg dry wt.) } \\
\cline { 3 - 5 } & & $\mathbf{2 0 0}$ bar $/ \mathbf{3 0}^{\circ} \mathbf{C}$ & $\mathbf{2 0 0}$ bar $/ \mathbf{5}^{\circ} \mathbf{C}$ & $\mathbf{1}$ bar $/ \mathbf{3 0}^{\mathbf{}} \mathbf{C}$ \\
\hline A 4637 & A. terreus & 30.0 & $31.2^{*}$ & 134.5 \\
\hline A 4636 & A. terreus & 38.4 & 7.7 & 132.7 \\
\hline A 4634 & A. terreus & 18.3 & 19.6 & 156.3 \\
\hline A 4633 & A. terreus & 20.8 & 19.8 & 121.3 \\
\hline A 4630 & Aspergillus sp. & 25.6 & 9.0 & 126.7 \\
\hline A 4628 & A. terreus & 10.0 & $13.7^{*}$ & 118.3 \\
\hline A 61 P10 & A. terreus & 20.6 & 12.9 & 125.7 \\
\hline A 61 P4 & Unidentified & 17.8 & $27.1^{*}$ & 128.2 \\
\hline A 4625 & Unidentified & 65.2 & 13.8 & 140.2 \\
\hline A 614 & A. terreus & 8.1 & 2.9 & 59.6 \\
\hline A 6137 & Unidentified & 15.4 & 6.5 & 71.6 \\
\hline A 3457 & Fusarium sp. & 21.1 & $29.6^{*}$ & 228.0 \\
\hline A 3449 & Fusarium sp. & 14.2 & 10.1 & 125.8 \\
\hline A 3441 & Unidentified & 31.5 & $38.9^{*}$ & 178.0 \\
\hline A 348 & Non- & 4.7 & $5.4^{*}$ & 64.3 \\
& sporulating & & & \\
\hline A 3428 & Curvularia sp. & 4.5 & $19.3^{*}$ & 175.7 \\
\hline A 61 P63 & Yeast & 23.4 & 9.1 & 249.2 \\
\hline A 3426 & Unidentified & 21.0 & $22.2^{*}$ & 234.6 \\
\hline A 6136 & Aspergillus sp. & 20.0 & 9.1 & 169.2 \\
\hline A 6139 & Unidentified & 17.5 & 15.4 & 171.4 \\
\hline A 61 P64 & Yeast & 12.2 & $16.8^{*}$ & 150.7 \\
\hline A 6128 & Aspergillus sp. & 9.3 & 9.3 & 165.7 \\
\hline A 6126 & Aspergillus sp. & 9.8 & 8.9 & 203.4 \\
\hline A 3415 & Unidentified & 1.7 & $11.3^{*}$ & 105.3 \\
\hline A 3412 & Aspergillus sp. & 3.1 & 1.7 & 140.0 \\
\hline Fungi sho & Ang & & \\
\hline
\end{tabular}

${ }^{*}$ Fungi showing better growth at $5^{\circ} \mathrm{C}$ than at $30^{\circ} \mathrm{C}$ under 200 bar pressure 
Table 5. Germination of spores of the deep-sea isolate Aspergillus terreus (\# A4634) and the terrestrial Aspergillus species from Microbial Type Culture Collection, Chandigarh, India.

\begin{tabular}{|c|c|c|c|c|}
\hline \multirow[t]{2}{*}{ Culture } & \multicolumn{4}{|c|}{$\%$ germination } \\
\hline & $200 \mathrm{bar} / 30^{\circ} \mathrm{C}$ & $200 \mathrm{bar} / 5^{\circ} \mathrm{C}$ & $1 \mathrm{bar} / 30^{\circ} \mathrm{C}$ & $1 \mathrm{bar} / 5^{\circ} \mathrm{C}$ \\
\hline $\begin{array}{l}\text { Aspergillus terreus } \\
\text { MTCC } 279\end{array}$ & $1 \pm 3.1$ & \multirow{4}{*}{$\begin{array}{c}\text { No } \\
\text { germination }\end{array}$} & $92 \pm 7.2$ & \multirow{4}{*}{$\begin{array}{c}\text { No } \\
\text { Germination }\end{array}$} \\
\hline $\begin{array}{c}\text { Aspergillus terreus } \\
\text { MTCC } 479\end{array}$ & $0.5 \pm 5.6$ & & $94 \pm 6.3$ & \\
\hline $\begin{array}{l}\text { Aspergillus sydowii } \\
\text { MTCC } 635\end{array}$ & 0 & & $91 \pm 6.7$ & \\
\hline $\begin{array}{c}\text { Aspergillus terreus } \\
\text { - deep sea isolate } \\
\text { A } 4634\end{array}$ & $66 \pm 26.7$ & & $94 \pm 8.1$ & \\
\hline
\end{tabular}


Table 6. Comparison of biomass produced by the deep-sea isolates and the terrestrial species obtained from Microbial Type Culture Collection, Chandigarh, India and some shallow water cultures isolated from Lakshadweep coral reef slope. Mycelial inocula were used.

\begin{tabular}{|c|c|c|c|c|}
\hline \multirow[t]{2}{*}{ Culture } & \multicolumn{4}{|c|}{ Biomass produced by the fungi (mg) } \\
\hline & $1 \mathrm{bar} / 30^{\circ} \mathrm{C}$ & 200 bar $/ 30^{\circ} \mathrm{C}$ & $1 \mathrm{bar} / 5^{\circ} \mathrm{C}$ & 200 bar $/ 5^{\circ} \mathrm{C}$ \\
\hline & \multicolumn{4}{|c|}{ Deep-sea isolates } \\
\hline $\begin{array}{l}\text { A. terreus } \\
\text { (\# A 4634) }\end{array}$ & 11.2 & 8.9 & 5 & 9.6 \\
\hline $\begin{array}{l}\text { Aspergillus sp } \\
\text { (\#A 61 P4) }\end{array}$ & 4.6 & 3.0 & 2.5 & 2.0 \\
\hline $\begin{array}{l}\text { Unidentified } \\
\text { (\#A 3415) }\end{array}$ & 10.5 & 8.0 & 6.2 & 5.0 \\
\hline $\begin{array}{c}\text { Aspergillus sp } \\
\text { (\# A 6128) }\end{array}$ & 10.0 & 3.3 & 1.9 & 1.6 \\
\hline $\begin{array}{c}\text { Cladosporium sp } \\
\text { (\#A 6136) }\end{array}$ & 3.7 & 0.9 & 1.4 & 1.5 \\
\hline $\begin{array}{l}\text { Non-sporulating } \\
\text { (\# A 3428) }\end{array}$ & 1.9 & 0.4 & 0.7 & 0.6 \\
\hline $\begin{array}{c}\text { Orange yeast } \\
\text { (\#A 61P63) }\end{array}$ & 1.9 & 1.3 & 1.5 & 1.3 \\
\hline $\begin{array}{l}\text { Off-white yeast } \\
\text { (\#A 344) }\end{array}$ & 6.6 & 1.0 & 3.3 & 1.7 \\
\hline \multicolumn{5}{|c|}{ Terrestrial and shallow-water isolates } \\
\hline $\begin{array}{c}\text { Aspergillus terreus } \\
\text { MTCC \# } 279\end{array}$ & 12.7 & 6.2 & 4.7 & 6.6 \\
\hline $\begin{array}{l}\text { Aspergillus terreus } \\
\text { MTCC \# } 479\end{array}$ & 10.6 & 7.7 & 4.3 & 10.4 \\
\hline $\begin{array}{c}\text { Aspergillus sydowii } \\
\text { MTCC \# } 635\end{array}$ & 12.6 & 7.6 & 9.3 & 6.3 \\
\hline $\begin{array}{l}\text { Shallow water non- } \\
\text { sporulating form } 1 \text {. }\end{array}$ & 16.1 & 0 & 5.0 & 9.3 \\
\hline $\begin{array}{l}\text { Shallow water non- } \\
\text { sporulating form } 2 \text {. }\end{array}$ & 17.1 & 7.7 & 10.1 & 5.7 \\
\hline $\begin{array}{l}\text { Shallow water non- } \\
\text { sporulating form } 3 \text {. }\end{array}$ & 13.3 & 4.9 & 6.7 & 3.4 \\
\hline
\end{tabular}


Table 7. Number of fungi surviving and showing active growth after exposure to sequential increase of hydrostatic pressure. All experiments were carried out at $30^{\circ} \mathrm{C}$.

\begin{tabular}{|c|c|c|}
\hline & \multicolumn{2}{|c|}{ Total fungi tested - 109 } \\
\hline $\begin{array}{c}\text { Incubation } \\
\text { pressure }\end{array}$ & $\begin{array}{c}\text { Viable, but not } \\
\text { growing }\end{array}$ & $\begin{array}{c}\text { Actively } \\
\text { Growing }\end{array}$ \\
\hline $\mathbf{5 0}$ bar & 32 & 74 \\
\hline $\mathbf{1 0 0}$ bar & 39 & 42 \\
\hline $\mathbf{2 0 0}$ bar & 6 & 16 \\
\hline $\mathbf{3 0 0}$ bar & 8 & 3 \\
\hline $\mathbf{4 0 0}$ bar & 2 & 1 \\
\hline
\end{tabular}

*Viability tested by plating on MEA medium. 


\section{Legends to Figures}

Fig. 1. Map of the Central Indian Basin showing within inset location of the sampling sites $\left(9-16^{\circ} \mathrm{S}\right.$ and $\left.73-76^{\circ} \mathrm{E}\right)$ during cruises AAS 34 , AAS 46 and AAS 61.

Fig. 2. Aspergillus sp. isolated from deep-sea sediments with abnormal morphology, showing hyphae in place of metulae and conidia-bearing phialides on the surface of the vesicle. Bar represents $10 \mu \mathrm{m}$.

Fig. 3. An epifluorescence microscopy photograph of a Calcofluor-stained germinating spore from deep-sea sediments $(0-2 \mathrm{~cm}$ subsection of a core) incubated under 400 bar pressure and $5^{\circ} \mathrm{C}$. Bar represents $10 \mu \mathrm{m}$.

Fig. 4. An epifluorescence microscopy photograph of a fungal hypha from a deep-sea sediment sample stained with Calcofluor. Bar represents $10 \mu \mathrm{m}$.

Fig. 5a. Immunofluorescence detection of a hypha of Aspergillus terreus (isolate \# A 4634) from 15-10 cm depth of a core of the deep-sea sediment treated with FITC-tagged polyclonal antibodies raised against the fungus. Bar represents $10 \mu \mathrm{m}$.

Fig. 5b. Bright-field photomicrograph of the same hypha as in Fig. 5a. Bar represents $10 \mu \mathrm{m}$.

Fig. 5c. Immunofluorescence detection of a dense cluster of hyphe of Aspergillus terreus on an organic particle from $15-20 \mathrm{~cm}$ core of a deep-sea sediment treated with FITC-tagged polyclonal antibodies raised against the fungus. Bar represents $10 \mu \mathrm{m}$.

Fig. 6. Photomicrographs of Aspergillus terreus (isolate \# A 4634) showing a) normal hyphae during growth at $1 \mathrm{bar} / 30^{\circ} \mathrm{C}$, and b) Abnormal hyphae with swellings during growth $200 \mathrm{bar} / 5^{\circ} \mathrm{C}$. Bars represents $10 \mu \mathrm{m}$. b) was photographed under phase contrast.

Fig. 7. Nomarski Differential Interference Contrast photomicroagraphs of the yeast (isolate \# A 344) showing a) normal growth at $1 \mathrm{bar} / 30^{\circ} \mathrm{C}$ and b) normal growth with abundant pseudomycelia at $200 \mathrm{bar} / 5^{\circ} \mathrm{C}$ (arrow). Scale $10 \mu \mathrm{m}$.

Fig. 8. Spores of Penicillium sp. (isolate \# 4615) showing normal germination at $300 \mathrm{bar} / 30^{\circ} \mathrm{C}$. Scale $10 \mu \mathrm{m}$.

Fig. 9. Spores of Aspergillus sp. (isolate \# 3454) germinating at $300 \mathrm{bar} / 30^{\circ} \mathrm{C}$. Note the swollen conidia (arrow). Scale $10 \mu \mathrm{m}$.

Fig.10. a) Epifluorescence microscopy of a fungal hypha in a transparent exopolymeric particle (TEP) collected from $30 \mathrm{~m}$ depth in the Arabian Sea. TEP was stained with Calcofluor and photographed under blue light with an epifluorescence microscope. Scale $10 \mu \mathrm{m}$. b) The same hypha photographed under bright field. Scale $10 \mu \mathrm{m}$. 


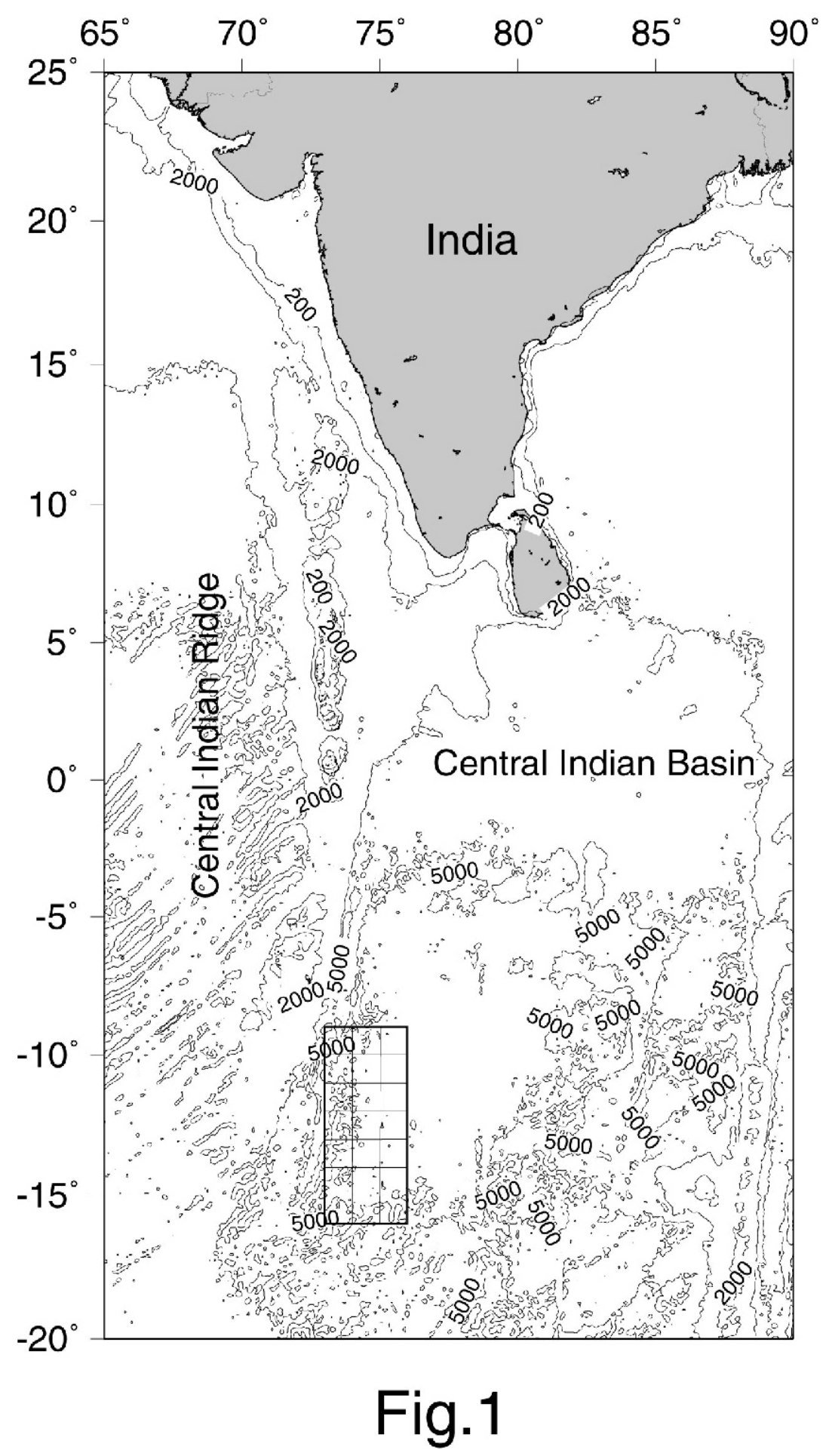




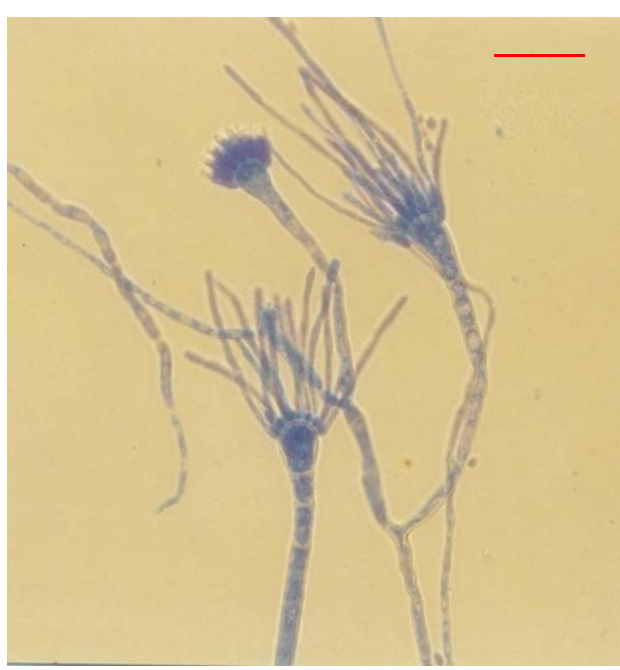

Fig 2

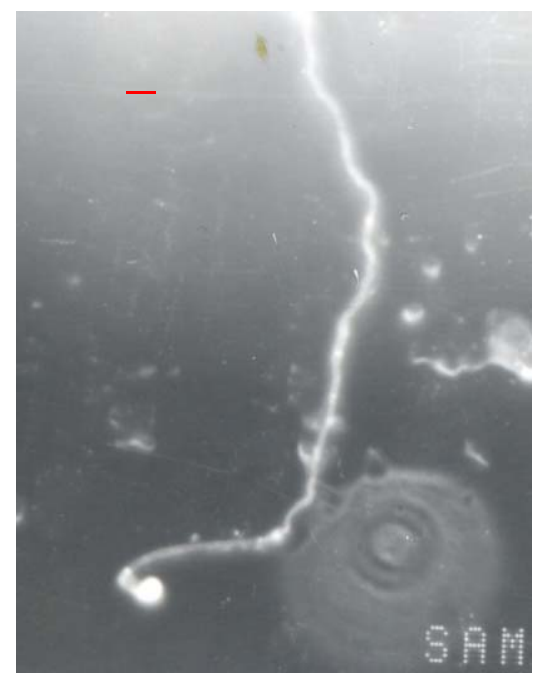

Fig 3

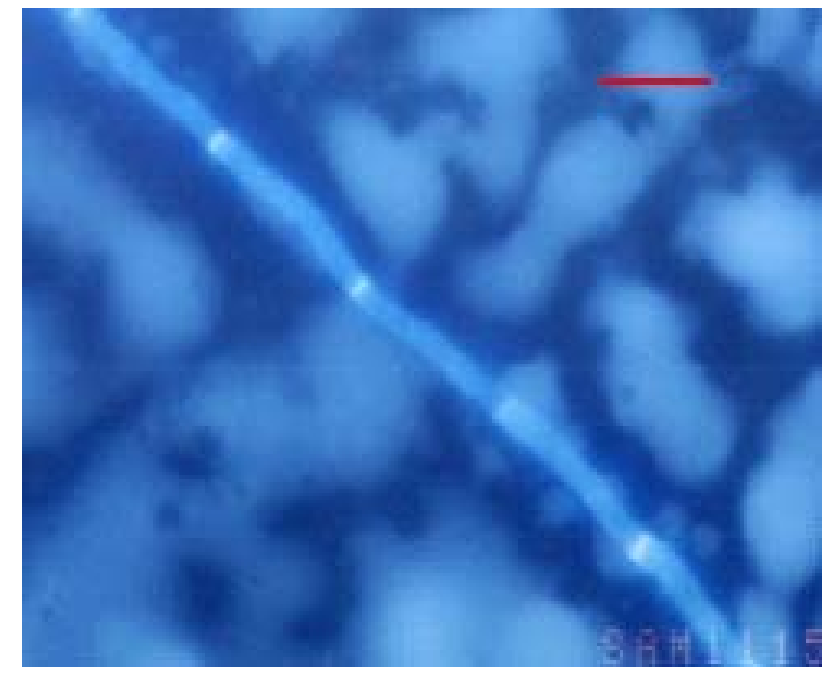

Fig 4
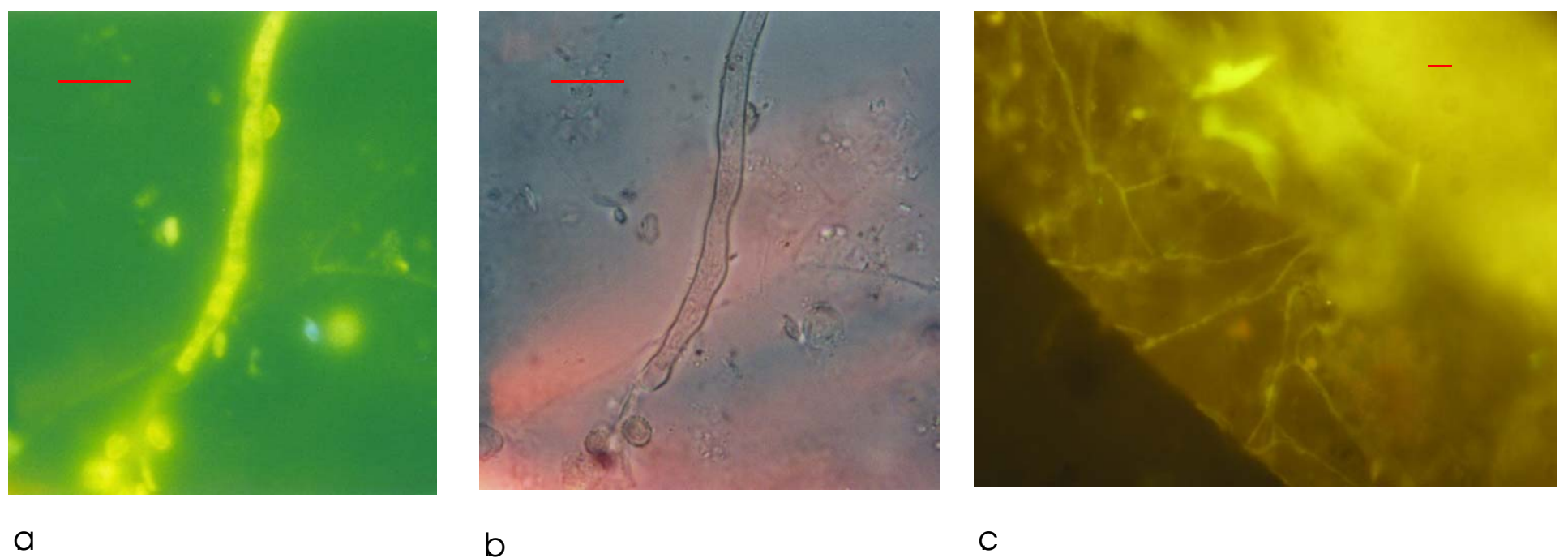

b

Fig. 5 


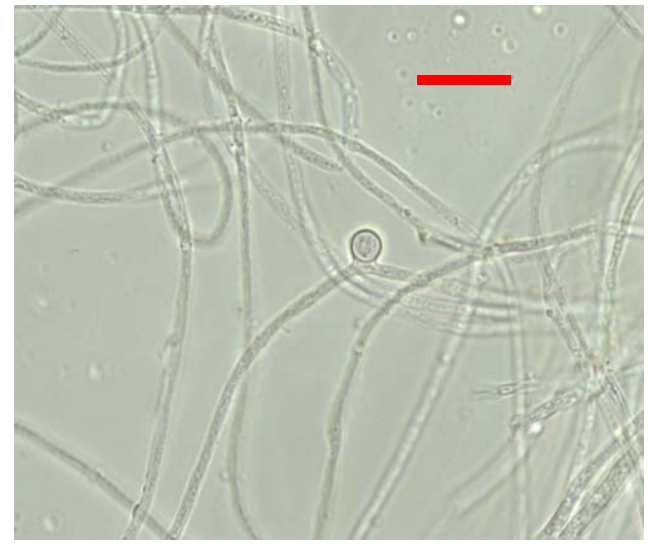

a.

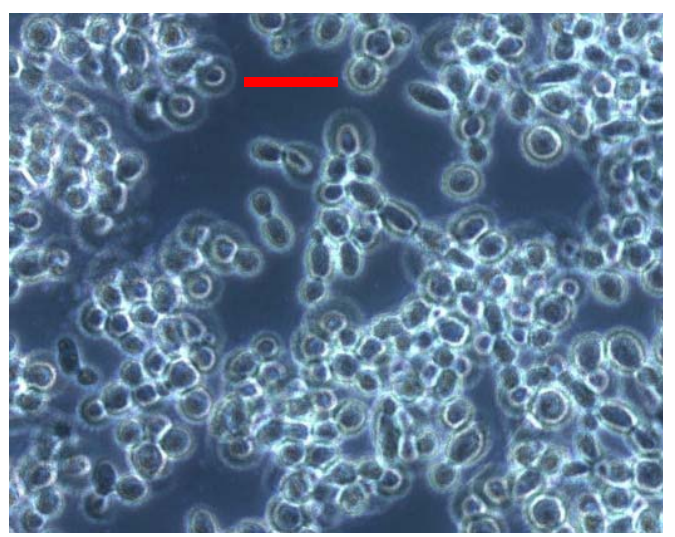

a.

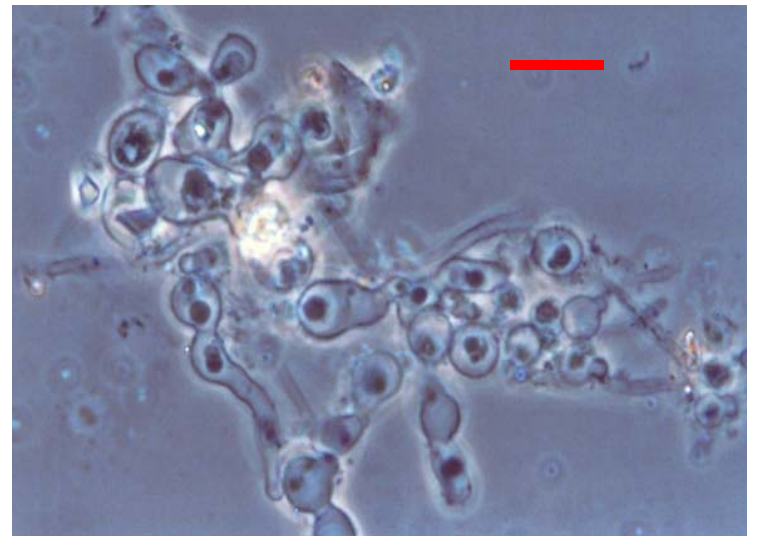

b.

Fig.6

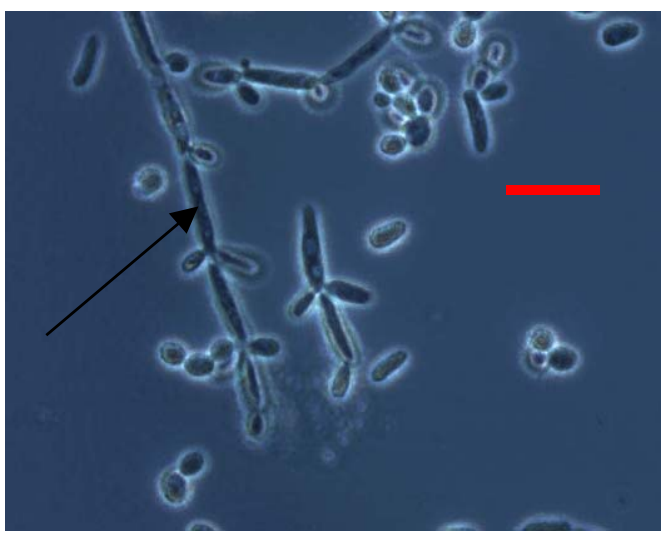

b.

Fig 7 


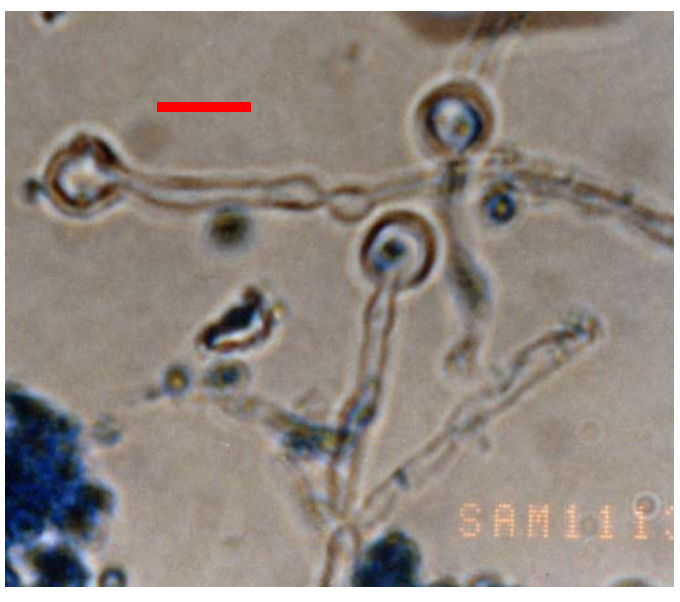

Fig 8

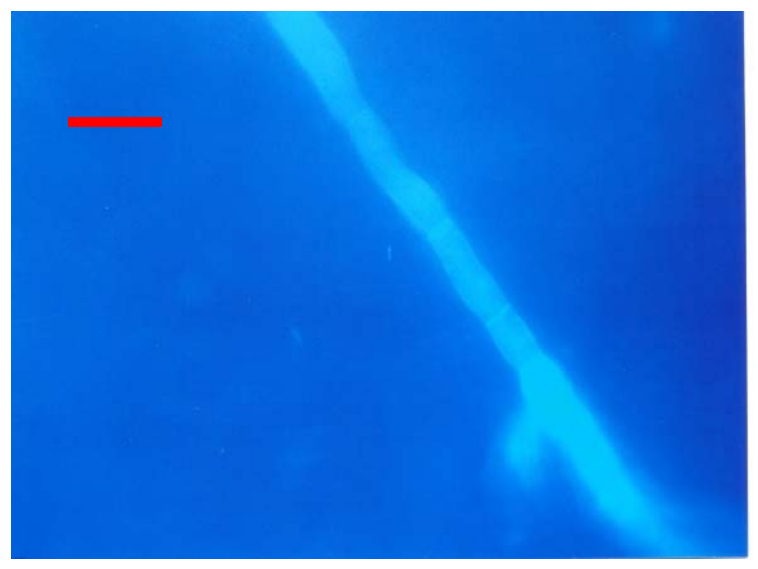

a.

Fig 10

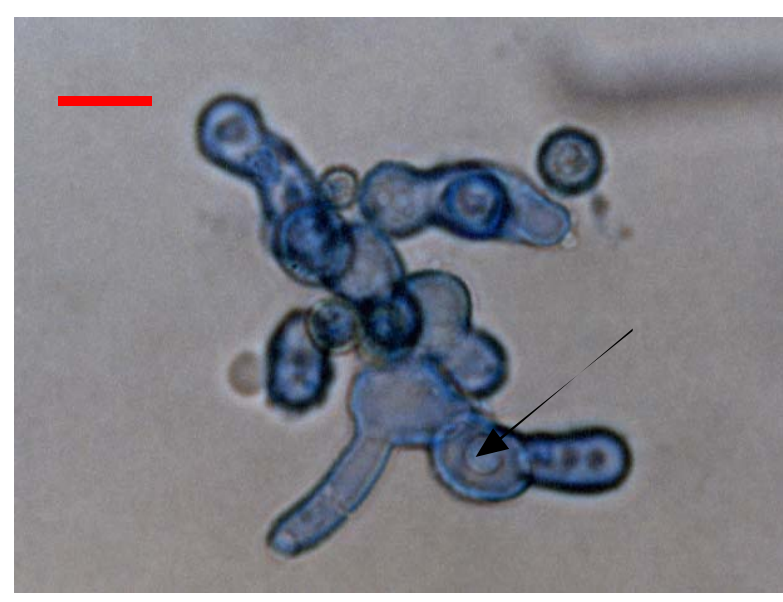

Fig 9

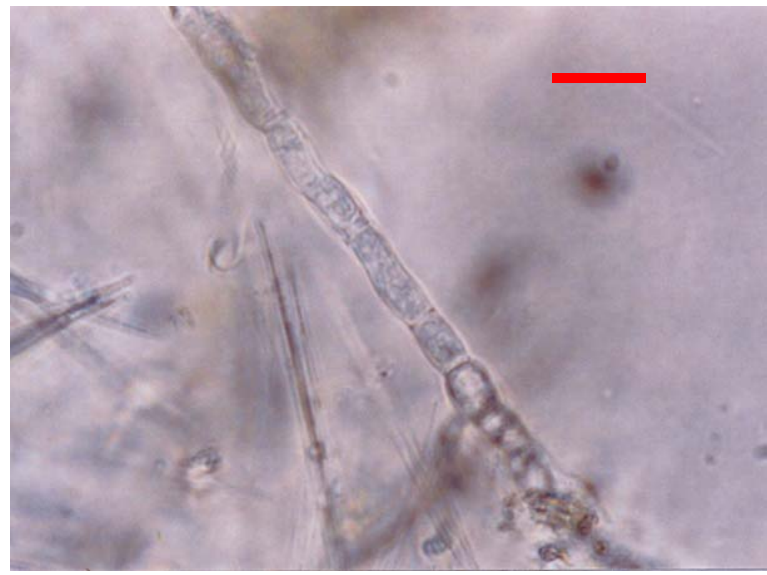

b. 